\title{
CROSS-CULTURAL IDEAS \\ OF AMERICAN AND UKRAINIAN STUDENTS \\ OF THE CONCEPT OF A SOCIALLY SUCCESSFUL PERSON
}

In Happiness And Contemporary Society : Conference Proceedings Volume (Lviv, March, 20-21, 2021). Lviv: SPOLOM, 2021. P. 247-250. https://doi.org/10.31108/7.2021.54

ISBN 978-966-919-697-2

ШАРКОВА Світлана, MANNING David

\section{КРОСКУЛЬТУРНІ ІДЕЇ}

\section{АМЕРИКАНСЬКИХ ТА УКРАЇНСЬКИХ СТУДЕНТІВ ЩОДО ПОНЯТТЯ СОЦІАЛЬНО УСПІШНОЇ ЛЮДИНИ}

// Щастя та сучасне суспільство : збірник матеріалів міжнародної наукової конференції (Львів, 20-21 березня 2021 р.). - Львів : СПОЛОМ, 2021. С. 247-250. https://doi.org/10.31108/7.2021.54

ISBN 978-966-919-697-2 
https://doi.org/10.31108/7.2021.54

SHARKOVA Svitlana

PhD in Psychology, Associate Professor

Postdoctoral researcher at G.S. Kostiuk Institute of Psychology of NAES of

Ukraine (Kyiv, Ukraine)

MANNING David

Professor of the Department of Social and Behavioral Sciences, Santa Fe College

(FL, USA)

\section{CROSS-CULTURAL IDEAS \\ OF AMERICAN AND UKRAINIAN STUDENTS OF THE CONCEPT OF A SOCIALLY SUCCESSFUL PERSON}

This research study has been conducted by a former Ukrainian Fulbright Scholarin-Residence in collaboration with American teaching staff. The students of an American college and a Ukrainian university were asked to outline the characteristics of a socially successful person answering the following questions:

What makes a person socially successful? Can you give examples of socially successful people?

What are the differences between socially successful and socially unsuccessful people?

Does social success correlate with the level of happiness?

Does success depend on the person or destiny?

These findings provide valuable insight into further development of teaching methods while encompassing cross-cultural facets into educational process.

Keywords: concept of a socially successful person, analysis of survey data, students of an American college, students of a Ukrainian university.

ШАРКОВА Світлана

кандидат психологічних наук, доиент, докторант

Інституту психології Г.С. Костюка НАПН України (Київ, Украӥна)

MANNING David

Professor of the Department of Social and Behavioral Sciences, Santa Fe College

(FL, USA)

\section{КРОСКУЛЬТУРНІ ІДЕЇ АМЕРИКАНСЬКИХ ТА УКРАЇНСЬКИХ СТУДЕНТІВ ЩОДО ПОНЯТТЯ СОЦАЛЬНО УСПІШНОЇ ЛЮДИНИ}

В результаті співпраці українських та американських фахівців завдяки програмі імені Фулбрайт вдалося організувати низку навчальних проєктів та емпіричних досліджень, серед яких представлене в даній публікації опитування. Студентам американського коледжу та українського вишу був запропонований адаптований опитувальник дослідниці Тугушевої А.Р. для порівняння уявлень представників різних культур про соціально успішних / неуспішних людей, роль 
власних зусиль та долі на формування такого успіху, взаємозв'язок успішності із почуттям щастя. Порівняльний аналіз відповідей учасників даного дослідження виявляє певні відмінності та спільні риси представників різних культур, що може бути використано для планування та покращення відповідних навчальних програм.

Ключові слова: уявлення про соціально успішну людину, аналіз даних опитування, студенти коледжу США, студенти вишу України.

Such international educational exchange programs as Fulbright Scholar-inResidence enhance participants to compare different educational systems, curriculum standards, student group community and age variations, etc. It is known that the specific classroom management and learning strategies in post-Soviet countries (like Ukraine) differ from American approaches. Still, the key priorities for educators all around the world in such dynamic, global and increasingly virtual environments highlight the importance of creating sound basis for student's intellectual, emotional and social selfdevelopment. In order to understand what can motivate students towards selfdevelopment, what aspects of activity can be considered as meaningful and significant, what social achievements are regarded by the youth as valuable, we asked students to complete the survey which was adapted from research studies conducted by Tugusheva (2007) and Moskalenko (2014). The received data from our empirical study will be briefly discussed in this paper.

This survey was conducted in 2018/2019 and involved 23 students from Santa $\mathrm{Fe}$ College (Gainesville, Florida) and 17 students from National Metallurgical Academy of Ukraine (Dnipro, Ukraine). The age range of the first group was 18-32 years old, and the second group participants were 17-20 years old. At the beginning students were asked to define what makes a person socially successful, what characteristics he/she has and who they consider as socially successful people. While analysing the responses of students we calculated the qualities which were mentioned by the participants more often.

The most frequently used characteristics of a socially successful person that have been outlined by Ukrainian students are (1) being sociable, affable. This includes descriptions of a personality who has a plethora of connections with other people, uses language that characterises well-educated person, follows etiquette and displays good manners. (2) The second group of mostly often mentioned characteristics comprises selfconfidence, self-discipline and self-regulation. These qualities referred to a person's ability to control, even restraint him/herself and not demonstrate inappropriate emotions in certain situations. (3) The third characteristic is orientation towards setting and achieving goals. Finally, there were two other features frequently mentioned, but less than the previous ones. According to students 'opinion, socially successful people should be creative (although the most common translation of this Ukrainian word is "creative", but its meaning can be quite close to the English word "open-minded" person). Plus, this category of people should be striving towards self-development.

American students described the following features of a socially successful person. First of all (1), such people should be willing to "give", share with the world, not just take and consume. (2) Second, they should be well-off, have financial stability, be able to manage money and other material resources. And some of the students have included higher education in this category as an indication of human's prosperity. (3) The third frequently mentioned characteristic was the positive attitude of a person and feeling of 
happiness. Some students have also connected it with self-satisfaction, self-confidence (the characteristic which was also outlined by Ukrainian participants). And the other two features were popularity of the person and open-mindedness. (The analysis of the replies helped us figure out from American students' descriptions that this word is similar to the one Ukrainian youth used). It would be interesting to point out that both Ukrainian and American participants also indicated high responsibility of a person as another important quality.

In addition, American students specified famous sportsmen, politicians from different countries and some inventors as examples of socially successful people. Six American students even included their relatives into this category. Surprisingly, Ukrainian participants provided examples very rarely, and it included bloggers, singers, politicians.

While analysing the next question about the differences between socially successful and socially unsuccessful people we have paid attention to the tendency of some students to start their descriptions with negative features that characterise unsuccessful category of people. It was $25 \%$ of Ukrainians compared to $22 \%$ of American participants who did this way. It can mean that these students are less oriented towards success (while concentrating on the description of "unsuccessful" qualities), or they put more effort in order to escape failing.

Nevertheless, American students emphasised that socially successful people accomplish their goals, stay more motivated, work hard, try to be the best, strive for the perfection, and stay happy. Socially unsuccessful people are lazy, don't want to bring changes in their lives, not responsible, have lack of connections with society, prefer staying in comfort zone, and pay no attention to their self-development.

Ukrainian students have underlined that the difference is in social status, connection with society, feeling of happiness, comfort and self-satisfaction. Some students have pointed out such qualities as stress-resilience and positive mindset. According to the submitted answers, attitude towards work defines the rate of success that can be achieved by a person. As another important quality (which was not mentioned at all by American participants, but was highlighted by Ukrainians) students listed an opportunity of having independence and being independent. In addition to several characteristics mentioned above that can be applied to a socially unsuccessful person, there were also low self-esteem, identity crises (or lost of identity), and selfisolation (psychological and physical).

Another discussed subject regarding the correlation of social success with the level of happiness revealed that $87 \%$ of American students have supported the idea of its positive correlation vs the rest of $13 \%$. At the same time, only $47 \%$ of Ukrainians have supported the interrelation of social success and high level of happiness, $23 \%$ have not agreed with it, and $30 \%$ have expressed their doubt explaining that it can depend a lot on the situation. The latter suppose, there can be well-known people with lots of followers especially in social networks, and they still can feel depressed, even lonely, etc.

Finally, the question whether success depends on the person or destiny has confirmed that majority of students do accept that it depends on the person. Two students (one American \& one Ukrainian) have stated that it is 50/50. Still, 24\% of American participants supported the idea that destiny plays more crucial role in it. In case with Ukrainian respondents it was $26 \%$. It is important to take into account initial genetic 
components of human beings' abilities and their needs as essential sources and activity motives that are regarded as vis vitalis (life energy) which create human's personality (Maksymenko, 2020).

We understand that for the further improvement of such research study it is better to leverage the age of participants. It should be also taken into account that in case with American students there are representatives of many cultures (including other foreign countries) that we have not tracked during this survey. Moreover, for more reliable research it is reasonable to engage students from different universities and different colleges because the level of students may vary. Still, such findings can be helpful for developing a range of social programs, special face-to-face or online courses, and international partnership enhancement.

\section{REFERENCES}

1. Maksymenko S. Genetic Psychology: Problems and Perspective (Basics of Concept)/ Maksymenko S.// Fundamental and Applied Researches In Practice of Leading Scientific Schools. - 2020. - $\quad$ № 40 (4). $\quad-\quad$ PP. 27-33. https://farplss.org/index.php/journal/article/view/720/673

2. Москаленко В.В. Особливості змістовних характеристик структурних компонентів уявлень студентів про соціально успішну людину/ В.В. Москаленко// Актуальні проблеми психології: зб. наукових праць Інституту психології імені Г.С. Костюка НАПН України / [ред. кол.: С.Д. Максименко (гол. ред.) та ін.] - К.: Вид-во “Фенікс", 2014. - Том ХІІ. - Психологія творчості - Вип. 20. - С. 191-203.

3. Тугушева А.Р. Представление о социальной успешности и личное самоопределение юношества: автореф. дис... канд. псих. Наук: 19.00.05/ А.Р. Тугушева; Удмурский ГУ. --Самара, 2007. - 24 с. 